\title{
Pedophilia and Child Sexual Abuse: A Socio Legal Perspective
}

\author{
Gargi Whorra* and Sudipto Mitra ${ }^{\dagger}$
}

\begin{abstract}
Societies worldwide have time and again turned a cold shoulder towards the heinous offence of child sexual abuse, until recent times when such hidden skeletons have walked out of closed cupboards, ranging from clergymen to the preposterously grotesque Nithari incident. This paper throws light on the growing foothold of child sexual abuse in the country by analysing it through varying dimensions. The paper seeks to examine the veracity of the situation of children, especially in a country like India, where the victim, irrespective of his innocence and fragility, loses his voice in the hullabaloo of the dogmas of the society. It is for such societal barriers that the rights of children did not see the light of the day till the year 2012. This article discusses the attempts made to check the child sexual abuse which have been made through legal initiatives and judicial decisions, both at the national and international level. The paper analyses the current situation in India with regard to child sexual abuse, while primarily drawing attention to the recent Protection of Children from Sexual offences Act, 2012 and pointing out the lacunae and shortcomings of the Act in dealing with the peculiar nature of the problem.
\end{abstract}

Keywords: Child Protection; Child Rights; Child Sexual Abuse; Pedophilia; Pederasty

* Third Year, BA LLB, Hidayatullah National Law University, Raipur; gargiw.hnlu@gmail.com

${ }^{\dagger}$ Second Year, BA LLB, Hidayatullah National Law University, Raipur 


\section{Introduction}

Pedophilia and child sexual abuse has undeniably been in existence for centuries. Pedophilia is a paraphilia that involves an abnormal interest in children. A paraphilia is a disorder that is characterized by recurrent intense sexual urges and sexually arousing fantasies. ${ }^{1}$ It can also be agreed that pedophilia is a psychosexual disorder ${ }^{2}$ wherein the methods of auto eroticism and actual act of engaging in sexual activity with pre pubertal children of the same sex or of the other sex is preferred. The sexual behaviors involved in pedophilia envelop an array of activities and may or may not involve the use of force.

Unfortunately, pedophiles do not come with the insignia of being child molesters. In India, peoples' collective conscience shook when the news of the massacre at Nithari ${ }^{3}$ broke. Incidents of pedophilia often go unnoticed, mostly due to the naive nature of the victim and otherwise due to taboo and societal pressure accompanied with its revelation. The child victim is often threatened by the pedophile against any disclosure. Hence, the ambit of sexual abuse is traumatic not only on the physiological growth, but also on the psychological well being of such a child.

\section{Pedophilia in the Contemporary World}

A gruesome illustration of pedophilic crimes in India reclines on the case of Sakshi $v$. Union of India. ${ }^{4}$ This case demonstrated the flaws in the Indian legal system which did not consider the heinous act of lust as rape and the High Court found the accused guilty for

1 ENCYClOPEDIA OF MENTAL DisORDERS, available at http:// www.minddisorders.com/Ob-Ps/Pedophilia.html (last visited Feb. 5, 2013).

2 Id.

3 Neelam Raaj, Children at Risk, (Jan. 14, 2007) available at http:// articles.timesofindia.indiatimes.com/2007-01-14/special-report/

27872204_1_nithari-migrants-crimestats.

${ }^{4}$ A.I.R. 2004 S.C. 3566. 
lesser offences of outraging the modesty of women and causing hurt.

In India, the government commissioned survey reported that more than $53 \%$ percent of children in the country were subjected to sexual abuse though a majority of the cases went unreported. ${ }^{5}$ According to the women and child development ministry sponsored report, those in the age group of 5- 12 years reported higher levels of abuse, ${ }^{6}$ which assumes greater implication in the milieu of the massacre at Nithari, a village in the periphery of the NCR where thirty eight children went missing and were suspected to be raped and then killed. The main accused of the killings, Surender Koli in his statement, described how he allured the girls and then strangulated them, ${ }^{7}$ had sex with their dead bodies and, ended up eating parts of their dead bodies. Being a rarest of the rare case the accused were sentenced to death by a Bench of Justice Markanday Katju and Gyan Sudha Mishra in 2007.

It is imperative to apprehend that such exploitation of children ensue as a result of power exercised over them. Another example could be that of Allan John Waters, convicted in 2008 on charges of sexual abuse of minor boys living in shelters ${ }^{8}$ run by him along with his colleague Duncan Alexander Grantthe. In the year 2000, rumours about sexual and physical abuse at Anchorage Shelter in

5 Over 53\% Children Face Sexual Abuse: Survey, TIMES OF INDIA, Apr. 10, 2007, http://articles.timesofindia.indiatimes.com/2007-04-10/india/ 27883340_1_child-abuse-sexual-abuse-corporal-punishment.

${ }^{6}$ Dave Warner, Prosecution Rests in Philadelphia Archdiocese Child Sex abuse Trial, CHICAGO TRIBUNE, May 18, 2012, http:// articles.chicagotribune.com/2012-05-17/news/sns-rt-us-usa-crimechurchbre84g1hd-20120517_1_defrocked-priest-abuse-trial-priestmolested.

7 Nithari Murders: Court Issues Surender Koli's Death Warrant, Mercy Plea Before President Filed, THE INDIAN ExPRESS, May 9, 2011, http:/ / www.indianexpress.com/ news/nithari-court-issues-kolis-deathwarrant-mercy-plea-filed/787967.

8 SC Restores Conviction of Two British Pedophiles, OuTLOOK, Mar. 18, 2011, http:/ / news.outlookindia.com/items.aspx?artid=715557. 
Mumbai run multiplied among the city's social workers community, when Childline India Foundation, a non- profit organization filed a petition in the High Court concerning the same. ${ }^{9}$

\section{Scaffold of Law}

\section{International Provisions relating to Rights of Children}

Among the various efforts taken by different countries and international organizations, United Nations Convention on the Rights of the Child, 1989 (hereinafter referred to as "UNCRC") gives children the right to be protected from sexual abuse. This Convention makes the signatory countries to take all national, bilateral, multilateral measures to prevent (a) the inducement or coercion of a child to engage in any unlawful sexual activity; (b) the exploitative use of children in prostitution and other unlawful practices; (and); (c) the exploitative use of children in pornographic performances and materials. ${ }^{10}$ Thus, it provides a framework for the protection of children by providing negative guarantees against the state. The state is duty bound to protect children from acts that are sexually forced upon them, and are illicit and abusive in character. The UNCRC has been ratified by $191^{11}$ countries including India.

\section{The Indian Scenario}

The Constitution of India incorporates some of the rights included in the UN Convention on the Rights of the Child as 'fundamental

${ }^{9}$ Childline India Foundation v. Allan John Waters, (2011) 6 S.C.C. 261.

10 The United Nations Convention on the Rights of Child art. 34, 1949, 1577 U.N.T.S. 3.

11 R. Barri Flowers, Runaway Kids and TeEnage Prostitution: AMERICA'S LOST, ABANDONED AND SEXUALly EXPLOITED CHILDREN 185 (2001). 
rights' and 'directive principles of state policy'.12 There are several assurances, meant specifically for children. Right to free and compulsory elementary education for all children in the 6-14 year age group ${ }^{13}$, right to be protected from any hazardous employment till the age of 14 years $^{14}$, right to be protected from being abused and forced by economic necessity to enter occupations unsuited to their age or strength ${ }^{15}$, right to equal opportunities and facilities for a healthy and dignified upbringing 16 and compulsory education and care in their preliminary years. ${ }^{17}$

The penal enactments by the legislature were however way too ill equipped to have incorporated the international mandates. The Indian Penal Code, 1860, India's prime criminal statute does not recognize pedophilia in any of its provisions. Due to the Code's unforthcoming conduct regarding pedophilic crimes and child sex abuse, the prosecutors are forced to rely upon the generalized terms that may not be adequate enough to furnish justice to such crimes. Generally, to criminalize sexual offenders of this prototype a wide interpretation of the provisions were put in force that criminalized sexual offences against women. Other forms of sexual crimes such as exhibitionism, the 'wrong' touch, penetration in any of the three orifices and insertion of any foreign object did not find any place in the Code. Outraging the modesty of women ${ }^{18}$ can also be contested in the court of law given that modesty of women is subject to judicial interpretation. In Sakshi $v$. Union of India ${ }^{19}$ this lacunae was widened when the court referred the matter to the

12 HAQ Centre for Child Rights, Constitution of India, available at http:/ / www.haqcrc.org/constitution-india (last visited Feb. 5, 2013).

13 THE CONSTITUTION OF INDIA art. 21A.

14 THE CONSTITUTION OF INDIA art. 24.

15 THE CONSTITUTION OF INDIA art. 39(e).

16 THE CONSTITUTION OF INDIA art. 39(f).

17 THE CONSTITUTION OF INDIA art. 45.

18 Indian Penal Code, Act No. XLV of 1860 § 354.

19 Over 53\% Children Face Sexual Abuse: Survey, supra note 5. 
legislature stating lack of proper definition of sexual abuse of children. Due to these shortcomings in the legal system necessity for protection of rights of children against sexual abuse and pedophilia was felt.

\section{The Protection of Children from Sexual Offences Act, 2012}

The Protection of Children from Sexual Offences Act, 2012, has been passed by the Lok Sabha on May 22, 2012. The Protection of Children from Sexual Offences Act, 2012 has been drafted to strengthen the legal provisions for the protection of children from sexual abuse and exploitation. For the first time, a special law has been passed to address the issue of sexual offences against children. ${ }^{20}$ The Act is, in itself, a remarkable positive step in recognizing not only the issues with regard to child sexual abuse but also takes intricate steps to tackle this enraging social issue.

While acknowledging the disadvantage that our adversarial legal system holds, especially with the recognition of the sensitivity of the victim, the Act provides for a special court so as to do away the verbal battle and balancing of evidence which happens in a normal court of law. This formation of special courts is a relief, keeping in mind the nature of trial and examination procedure adopted in a court of law and this attains paramount importance since often the only witness available in such a case is the abused child himself. Credit needs to be given to this Act for understanding the sensitivity of the victim and the nature of the offence committed against him or her and thus has provided for the establishment of special courts for trial of offences under the Act, keeping the best interest of the child at every stage of the judicial process.

The Act considers every person below the age of 18 years as a child. This interpretation is a victim oriented step and does much to do away with the debate over the clash of age of consent of the child in various legislations. Keeping in mind, the age limit of marriage for girls is 18, the Act is in consonance with the institution of marriage which prima facie encompasses in itself sexual intercourse and the requisite age of consent. Furthermore, an offence is treated as

${ }^{20}$ The Protection of Children from Sexual Offences Act, No. 32 of 2012. 
aggravated when committed by a person in a position of trust or authority of child, such as a member of security force, police officer, public servant etc. ${ }^{21}$

The Act ordains several chastisements for child sexual offenders. The Act also provides that penetrative sexual assault is punishable with imprisonment for not less than seven years which may extend to imprisonment for life, ${ }^{22}$ and fine. ${ }^{23}$ Aggravated penetrative sexual assault on the other hand is punishable for at least ten years which may extend to imprisonment for life, ${ }^{24}$ sexual assault is punishable for a period not less than three years which may extend to five years, ${ }^{25}$ sexual harassment of a child is punishable for three years with a fine ${ }^{26}$ and use of children for pornographic purposes and voyeurism is punishable with an imprisonment of five years and in case of conviction seven years along with a fine. ${ }^{27}$

The Act further incorporates child friendly procedures with regard to all the preliminary stages of trial of the offence and with regard to the trial itself. These measures are primarily recording the statement of the child at the residence of the child or at the place of his choice, preferably by a woman police officer not below the rank of sub inspector. Moreover no child is to be detained in the police station in the night for any reason, keeping in mind the psychological sensitivity of the child and the police officer is not be in uniform while recording the statement of the child. The statement of the child to be recorded as spoken by the child may be provided with assistance of an interpreter or translator or an expert as per the need of the child. The Act, while keeping in mind situations where the child is disabled has provided for the

21 The Protection of Children from Sexual Offences Act, 2012.

22 The Protection of Children from Sexual Offences Act, 2012 § 3.

23 The Protection of Children from Sexual Offences Act, $2012 \S 4$.

24 The Protection of Children from Sexual Offences Act, $2012 \S 5$.

25 The Protection of Children from Sexual Offences Act, 2012 § 7.

${ }^{26}$ The Protection of Children from Sexual Offences Act, $2012 \S 12$.

27 The Protection of Children from Sexual Offences Act, $2012 \S 13$. 
assistance of a special educator or any person familiar with the manner of communication of the child. All these measures are in consonance with the spirit of sensitivity required for such matters as had been stated by the Supreme Court in Sakshi v. Union of India 28 that - "Rules of procedure are handmaiden of justice and are meant to advance and not to obstruct the cause of justice. It is, therefore, permissible for the court to expand or enlarge the meanings of such provisions in order to elicit the truth and do justice with the parties".

The role and importance of the parents or a person whom the child holds in trust is further appreciated by making their presence necessary during medical examination of the child. In case the victim is a girl child, the medical examination shall be conducted by a lady doctor. The fragility of the child in terms of age and mental condition is kept in mind and thus the Act provides for frequent breaks for the child during trial, and the child would not be called repeatedly to testify. The Act so as to protect the social image of the child bars the media from disclosing the identity of the victim without the permission of the special court.

\section{Shortcomings of the Act}

The Act in its spirit is a misnomer since it does talk about protecting the child but only once the offence is committed, thus omitting any kind of preventive steps. The theory of punishment being a deterrent is extremely evident here but how effective will this deterrent be is open to much speculation, while keeping in mind past experiences. The Act has also raised the age of the child victim to 18 . In the course of it, the Act also penalizes any sexual activity, even a consensual one, with children under 18 or between minors.

The provisions in the Act relating to the age do not reflect upon the stark realities of post modern society due to conservatism and archaic conceptions. The fact cannot be denied that youth indulge in sexual acts. It would be unjust to penalize two consenting minors having consensual intercourse because the Act is silent. This lacuna

${ }^{28}$ Over 53\% Children Face Sexual Abuse: Survey, supra note 5. 
in the Act bears a hypocritical outlook to a social concern which needs sensitivity and care to prevent the misuse of such acts in the future and to give justice to true victims.

The need of the present day society is that the law should be such that it endorses in itself a flexible standard for determining the age of consent of minors to avoid legal anomalies especially in case of minors being punished at par with an adult. ${ }^{29}$ In this regard, one may take cognizance of legal systems which have addressed the issue more comprehensively like the law in Switzerland, where though the legal age of consent has been fixed at sixteen years, ${ }^{30}$ an exception has been carved out for cases where the age difference between the involved parties is three years or less. ${ }^{31}$

Similarly, in Israel, while sexual intercourse with a child below the age of fourteen years is considered to be statutory rape, irrespective of the consent, however if the child is between fourteen and sixteen years and the age gap between the two individuals is less than two years, consensual sexual intercourse is legal. ${ }^{32}$ The relativity of these laws rests in the fact that they endeavor to protect the child from sexual abuse whilst carving a reasonable exception in the case of minors engaging in intercourse consensually.

A further sensitization of the legislation is needed with regard to the initial addressing of the reporting of the incidents of abuse. The law has a victim-oriented, sensitized approach when it comes to the child but fails to encompass in itself persons and institutions which specialize in terms of child welfare and abuse cases. This aspect can be identified in the United States Federal Legislation ${ }^{33}$ which calls upon the law enforcement agencies and the social service bodies to

29 Tarunabh Khaitan, Still a Matter of Shame, THE TELEGRAPH, Apr. 24, 2006, available at http://www.telegraphindia.com/1060424/asp/ opinion/ story_6133573.asp.

30 SCHWEIZERISCHES StRAFGESETZbuCH [STGB] [CRIMINAL CODE] Dec. 21, 1937, SR 757 art. 187, ๆ 1 (Switz.).

31 STGB art. 187, 92.

32 Penal Law of Israel, 5737-1977 § 353.

3318 U.S.C. $\S 3509$ (2006). 
work together during investigation and trial for protecting and dealing with both the psychological and physiological trauma of a child sexually abused and this acts as a buffer system against retraumatisation during the process.

The biggest lacuna in the legislation can be seen in Chapter $\mathrm{V}$ of the Act which describes the procedure for reporting of cases. The ambit of this part of the legislation is too wide and thus invites misuse. The term 'any person' is used to indicate anyone who has reason to believe that an offence under this Act is likely to be committed or knows that such an offence has been committed any time in the past is obliged to inform the special juvenile police or the local police. Failure to report is considered a criminal offence punishable by imprisonment. Furthermore, the legislation provides for no punishment for a child who makes false accusations or provides false information. This provision is child friendly, at the same time there are no provisions in the Act to check whether the child has made a false allegation. The legislation does not provide for any provision relating to the protection of the persons other than a child, who reports the incident of abuse. The legislation also has no protection for whistle blowers.

In our country where $53 \%$ of the children (as surveyed by the Ministry of Women and Child) Development, reported one or more forms of sexual abuse. ${ }^{34}$ Mrs. Renuka Chowdhury rightfully said that India is a country where "there is a tradition of denying child abuse. It doesn't happen here is what we normally say. But by remaining silent, we have aided and abetted the abuse of

34 Over 53\% Children Face Sexual Abuse: Survey, supra note 5 (The study took two years to complete and covered 13 states where 12,247 children (between five and 12) and 2,324 young adults (over the age of 12) were quizzed. Dr. Loveleen Kacker, the official in charge of child welfare in the ministry, compiled the report. She said the study had revealed that contrary to the general belief that only girls were abused, boys were equally at risk, if not more. She said a substantial number of the abusers were "persons in trust and care-givers" who included parents, relatives and school teachers. Moreover more than $70 \%$ of the abuse had not been reported to anyone). 
children." 35 It would not be wrong to say that the Act was overdue since there was no special law to protect the abused child especially in severe cases like pedophilia. The irony lies in the fact that even after so many glooming instances of child abuse, increasing trend of pedophilia, the Nithari incident, the lawmakers took 20 years to make the present legislation even after having ratified the United Nations Convention on the Rights of Child, 1989. Hopefully this legislation is to act in the near future as the much needed beam of light for children shackled in the dark dungeons of sexual abuse, especially pedophilia.

\section{Conclusion}

This paper has made an attempt to highlight and assess the substantive and procedural aspects of the law protecting children against sexual abuse especially in the light of the recent enactment of the Protection of Children from Sexual Offences Act, 2012. But the mere fact that a legislation has been made is not going to be sufficient to protect the soul of our future generations from scars of sexual abuse. The myth that pedophiles and child abusers are predatory strangers needs to be dispensed ${ }^{36}$ and this can only happen by taking collective steps, out of which the quintessential one is to break the silence.

There is a need to create awareness about child abuse in a sensitized manner through non-governmental organizations, television broadcasts and governmental initiatives etc. This sensitization should not be targeted at the victim group alone but also to parents and guardians who remain oblivious of these crude realities due to lack of education and exposure. Child helpline numbers should be publicized for the benefit of the children. There

35 Geeta Pandey, Abuse of Indian Children 'Common', BBC NEWs, Apr. 9, 2007, available at http://news.bbc.co.uk/2/hi/6539027.stm.

36 Pessimism about Pedophilia, Harv. Mental Health LetTer, Jul., 2010. ("About $60 \%$ to $70 \%$ of child sexual abuse cases involving pedophiles, the perpetrator is a relative, neighbor, family friend, teacher, coach, or someone else in regular contact with the child"). 
also is a dire need to espouse sex education in the curriculum of educational institutions especially at the primary level. 